\title{
Development of alien and invasive taxa lists for regulation of biological invasions in South Africa
}

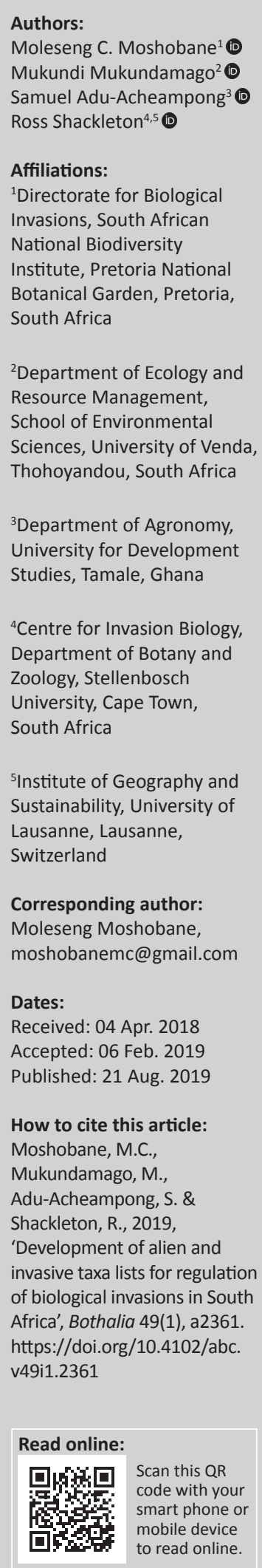

Background: Lists are fundamental for guiding policy and management of biological invasions. The process of developing regulatory lists of alien and invasive taxa should be based on scientific evidence through an objective, transparent and consistent process.

Objectives: In this study, we review the development of the lists for the alien and invasive species regulations in terms of section 97(1) of the National Environmental Management: Biodiversity Act, 2004 (NEM:BA) (Act No. 10 of 2004).

Method: Lists published in the National Government Gazette were compared and assessed for changes in the taxa listed and their status between 2009 and 2016. Minutes from expert workshops convened to inform the listing were reviewed. Relevant information such as the criteria for listing taxa was extracted from minutes of the workshops.

Results: Three draft versions were produced and published in the Government Gazette for public comment before the final list was published in August 2014 and promulgated in October 2014. The list is to be reviewed regularly and additional species can be added, and the status of species can be changed as additional evidence of threat levels is available - and was even amended in May 2015. The various stakeholders involved in the listing process were academics, conservation experts, managers and the general public through an inclusive process which included participation workshops or through public comment. A scoring tool based on the likelihood of invasion versus the impact of invasion was recommended for evaluating the risk of a species, but was rarely used. A number of issues relating to conflicts and approaches for listing were faced during development of lists.

Conclusion: We conclude with some recommendations for future refinements in the listing process, including improving transparency and participation as well as developing standardised approaches for listing.

Keywords: alien species; biological invasion; biosecurity; invasive species; legislative tools; management; policy; non-native species; regulation.

\section{Introduction}

The Convention on Biological Diversity (CBD 2002) considers invasive alien species (IAS) as a global concern because of their negative impact on biodiversity, which can also affect ecosystem services and human well-being (Pejchar \& Mooney 2009). The CBD's Aichi Target 9 includes a requirement that priority IAS need to be controlled or eradicated, a process that requires the development of species lists for specific management or regulation. The efforts to reduce the spread of IAS have been heightened in many countries and can involve various processes (Garcíade-Lomas \& Vilà 2015). Mechanisms to prevent the introduction of IAS (Lupi, Hoehn \& Christie 2003) can be implemented, and may include conducting risk assessments and monitoring pathways of entry into a given region (Early et al. 2016; Kil et al. 2015). Having lists of invasive or potentially invasive species aids in combating further introductions as well as helps with monitoring (McGeoch et al. 2010, 2012; Verbrugge et al. 2012). Furthermore, lists of all historical records of introduction of IAS play an integral part in managing invasive species (Kolar \& Lodge 2001). Lists can help guide prioritisation and aid in the implementation of species-specific or areaspecific management plans. Producing lists of alien and invasive species, or for example threatened taxa, has become a common practice in many countries as the first part of the management process (García-de-Lomas \& Vilà 2015; Pergl et al. 2016; Possingham et al. 2002; Protopopova, Shevera \& Mosyakin 2006). In addition, lists can be a useful indicator for measuring the effectiveness of management interventions (Butchart et al. 2010). For example, listing and monitoring of species has recently shown that some invasive species are undergoing population expansion, whilst others are declining because of effective management interventions (Henderson \& Wilson 2017).

Copyright: (C) 2019. The Authors. Licensee: AOSIS. This work is licensed under the Creative Commons Attribution License. 
However, lists are not without inaccuracies and can be complex to create (Jacobs et al. 2017; McGeoch et al. 2012). The reliability of regulatory lists largely depends on the processes followed in their development. Most importantly, the success of such listing processes can depend on available scientific evidence and the level of transparency allowed in the listing process (Simberloff 2003). The likely possible inefficiencies in the process of developing lists of regulated species include:

- Biases towards and away from species with obvious and high impacts on the ecosystems (García-de-Lomas \& Vilà 2015).

- Taxonomic uncertainty (Jacobs et al. 2017; Pyšek et al. 2008).

- Lack of information, monitoring and skills capacity (Burgman 2004).

- Little political will to do so (Morrison et al. 2010).

Furthermore, lists can only be effective and transparent through adequate stakeholder engagement (Shackleton et al. 2019). Hence, preventing conflict between generators of lists and other actors is important, and can be performed through an evidence-based, collaborative and transparent listing process (Butchart et al. 2010; Perry \& Perry 2008).

Legislation development is a cornerstone in preventing future invasions and managing current ones, and is dependent on accurate lists. For South Africa, the National Environmental Management: Biodiversity Act (NEM:BA) (Act no. 10 of 2004) seeks to bring biodiversity conservation into perspective by providing relevant management options against biological invasions. As part of this regulatory lists are required. Different approaches have been used to create these lists, and here we aim to give an insight into listing processes in South Africa. In this article, the specific aims include to:

- Review the process used to develop the lists for the South African NEM:BA alien and invasive species regulations.

- Document and analyse how the lists changed over time.

- Outline general issues faced in the listing process.

- Provide recommendations for future listing.

\section{Methods}

\section{Review of workshop minutes and assessments of lists}

To determine events that underpinned the development of NEM:BA invasive and alien species regulations list in South Africa, we reviewed minutes from expert workshops used to inform the listing process. Information extracted from these minutes includes: criteria and processes used for listing of taxa; species listed and decisions on how to deal with conflict species. (e.g. invasive species which draw much debate because of having both benefits and associated costs; see Zengeya et al. 2017). The degree of stakeholder engagement was assessed from the expert workshops by determining diversity of represented organisations and participants. We also reviewed email correspondences between key stakeholders to establish the sequence of events that took place. We further estimated the effort and financial resources spent on the development of the lists based on information from government documents. We also reviewed the differences in published lists over time.

\section{Results and discussion Development of the National Environmental Management: Biodiversity Act invasive alien species lists in South Africa}

The history of the National Environmental Management: Biodiversity Act listing process

Development of the IAS list for South Africa was first initiated in early 2005 and first publication of the list was in August 2014. According to Section 70 (1) (a) of the Act published in 2004:

'The Minister must within 24 months of the date on which this section takes effect, by notice in the Gazette, publish a national list of invasive species in respect of which this Chapter (Chapter 5) must be applied nationally.'

and thus should have been promulgated on 01 October 2006, a date that was not adhered to.

The drafting of regulations and species lists went through three phases. Compilation of the list commenced in 2004. The first list was completed in August 2006 by the official task team; the second draft list was compiled by the Department of Environmental Affairs and Tourism ([DEAT], later known as Department of Environmental Affairs [DEA]) in 2007 and now known as the Department of Environment, Forestry and Fisheries (DEFF). The listing process was delayed because of several factors, including changes in coordinating leadership, difficulties with recruitment of experts to compile taxonspecific lists, complex stakeholder engagement issues and conflicts, as well as uncertainty over listing procedures and approaches. Criticisms surrounding the second draft led to the establishment of round-table discussions between DEA and various stakeholders, hosted by the then DEA minister Mr M.J.C van Schalkwyk. This was done to help develop solutions for the ongoing issues in the listing process and guide progress and specific approaches for creating the list. Following these meetings, the South African National Biodiversity Institute (SANBI) was instructed by the DEA to take over the lead for the listing process.

\section{Task team and initial listing}

Because of the failure of the initial listing process, the second phase was led by a task team of experts from SANBI, starting April 2008. In January 2009, the first lists were sent to DEAT, whilst the consultation processes continued, and the lists were revised until a completed set of lists was submitted to DEA in 2014. During this period, there were communication breakdowns because of conflicting ideas among participants and different stakeholder groups. This was alluded to as one of the major obstacles hindering the progress of this exercise, and led to some participants abandoning discussions. 
The most controversial example was the disparate views of some fishing enthusiasts who opposed the inclusion of trout on the invasive species list (Woodford et al. 2016).

Various organisations were involved in the creation of the initial version of the list, with several expert stakeholder workshops (interest groups) focusing on specific taxa such as plant, mammal, reptile or amphibian and fish were held (see Appendix 1 for a list of represented organisations). The workshops for listing of different taxa were conducted in different manners and used different approaches; for example, in the initial phase, the list of plants was based largely on expert opinion, but later it was based on a risk assessment scheme (L. Henderson, unpublished scheme). On the other hand, the framework for listing of reptile species was developed from a mixture of both expert opinions and the use of risk ranking tools. Furthermore, the creation of the initial list for microbes was based only on expert consultation. A conceptual framework based on the likelihood of invasion versus the impact of invasion (Figure 1) was proposed for evaluating the risk of all species, but only the facilitator of reptile and amphibian expert working group applied the conceptual framework.

The first comprehensive list was published for public comment on 03 April 2009 and had a total of 548 taxa. This list was largely made up of plants (348 taxa). The listing of complete genera, families and orders was discussed, and a few were included (e.g. Dendrobates). However, most listings were for individual species. The task team noted that there were conflicts surrounding some of the listed taxa from the public, and hence the initial list was amended, for example, trout (see Appendix 1). The second version of the list was published for public comments on 19 July 2013. Notably, the lists from 2013 had only two categories, namely 1a and 1b, until amendments could be made to NEM:BA (Table 1). This is because NEM:BA originally stated that Chapter 5 (Alien and invasive species) applied nationally. This meant that the regulations would have to be applied countrywide to all listed species. It did not make provision for listing species differently by region or area. Consequently, the Act was changed on 24 July 2013 (Government Gazette No. 36703) to allow for the listing of species within regions or areas and Category 2 and 3 species were added (Figure 3). Broadly speaking, Category 1a species have to be combated and eradicated or controlled immediately and trade, use and planting must be prohibited; Category $1 \mathrm{~b}$ species must be controlled wherever possible and no further trade, use or planting is allowed; Category 2 are species that are invasive, but have value and therefore a permit is required to carry out activities relating to the species; and Category 3 are species that may remain in some prescribe areas (no need for active control), but no further planting, use or trade is allowed.

Because of time lags, Kloof Conservancy sought mediation from the KwaZulu-Natal court system, and a court judgement was issued compelling DEA to publish the list of IAS - leading

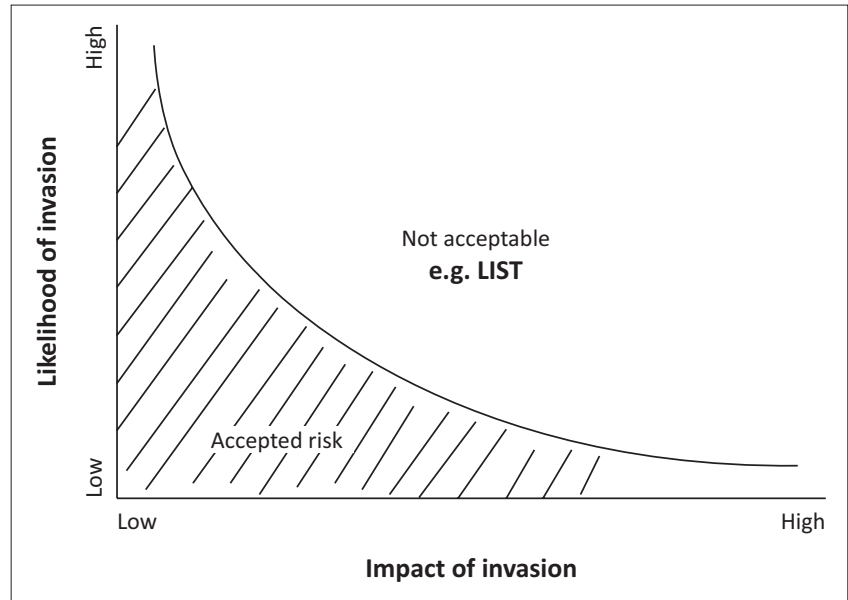

Source: Listing workshop minutes

FIGURE 1: A scoring tool used for reptile listing assessment (Anonymous 2008).

TABLE 1: Total listed, regulated and prohibited taxa according to the National Environmental Management: Biodiversity Act invasive alien species 2016 list including hybrids.

\begin{tabular}{lccc}
\hline National list invasive taxa & $\begin{array}{c}\text { Listed taxa or } \\
\text { species }\end{array}$ & $\begin{array}{c}\text { Listed and } \\
\text { regulated species }\end{array}$ & $\begin{array}{c}\text { Prohibited } \\
\text { species }\end{array}$ \\
\hline Terrestrial and freshwater plants & 379 & 403 & 238 \\
Marine plants & 4 & 4 & 2 \\
Mammals & 41 & 41 & 18 \\
Birds & 24 & 24 & 20 \\
Reptiles & 30 & 64 & 12 \\
Amphibians & 7 & 198 & 9 \\
Freshwater fish & 15 & 15 & 110 \\
Marine fish & 0 & 0 & 1 \\
Terrestrial invertebrates & 23 & 3158 & 131 \\
Freshwater invertebrates & 9 & 9 & 8 \\
Marine invertebrates & 17 & 17 & 7 \\
Microbial species & 7 & 7 & 7 \\
\hline Total & $\mathbf{5 5 6}$ & $\mathbf{3 9 4 0}$ & $\mathbf{5 6 3}$ \\
\hline
\end{tabular}

Note: Listed and regulated species refers to the individual species listed; if a genus was listed, this considers all member species of the listed genus.

to a rushed job. The version of the list published in July 2013 was declared unlawful and unconstitutional by the High Court of South Africa's KwaZulu-Natal local division because of pending issues like ongoing stakeholder engagements and conflict. A third updated version was published on 12 February 2014. Although issues that arose from this listing process were quickly resolved, there were other outstanding complaints from stakeholders. Addressing these outstanding issues caused substantial delays and the eventual failure to meet the NEM:BA timeline. This led to the final version of the IAS list that was officially published on 01 August 2014 and promulgated on the 01 October 2014 with 560 regulated taxa, and later in 2016 with 556 regulated taxa.

\section{Estimation of costs for the development process}

The process of IAS listing took nine years to complete. A conservative estimate of production cost was R6 million. This calculation was based on salary levels of key participants, and noting that the participants who took part in the initial task team did so pro bono, and that most of them were employed by local organisations, which directly or indirectly covered the costs (see Appendix 4 for calculations). 


\section{An analysis on how the lists changed over time}

The listing process resulted in three draft lists published in the Government Gazette for public comment before the final list was published (see Appendices 1-3). This list was proposed for amendment in May 2015 and the new and current version was published on 29 July 2016. The total number of listed invasive species differed notably across the draft versions of the lists (Figure 2). In the 2013 version, several taxa were removed from the 2009 proposed list, although some of the species that were removed were relisted again in later versions. One of the reasons for differences in the lists was that the NEM:BA lists should exclude those species listed under the Conservation of Agricultural Resources Act (CARA) (Act No. 43 of 1983).

\section{Analysis of current list of regulated and prohibited species (July 2016)}

The NEM:BA list of regulated IAS taxa, updated on 29 July 2016, is divided into two major categories: (1) regulated invasive taxa list containing a total of 556 taxa and a prohibited list with a total of 563 taxa, and (2) a prohibited list included seven complete genera, one family and one order with the rest being species. Prohibited taxa consists of 283 plant species, 131 invertebrate taxa and one marine fish and two marine plant species, whilst there were no marine fish species listed for regulation. Again, plants had the highest number of regulated species (379), followed by mammals with 41 species. However, considering the individual members in each entry above the species level, the current NEM:BA version regulates approximately 3793 species (from 556 listed taxa) and prohibits approximately 19000 species (synthesised from 563 taxa). For example, the Dendrobates genus has over 160 species and the whole genus is listed. Furthermore, there were several inconsistencies with the current list. These included the listing of hybrids of native species and inconsistency in the use of authorities along with the taxa (Appendix 2). There were systematic differences between the 2016 list and all the versions prior to $2014 \mathrm{~b}$, such as the use of two categories and the use of four categories and the listing of native species in 2009, but not in other years (Appendices 2 and 3).

\section{Challenges in the listing process}

The South African task teams working on the development of the lists of alien and invasive taxa reached consensus only after nine years and produced a final list. However, it is worth noting that lists development remains a continuous process. This is attributed to several challenges encountered in the process. The main challenge was to compile the list within the strict confines of the NEM:BA regulation. For example, some taxa were listed without a standardised risk assessment process, but based on expert opinion except for plants and reptiles. This led to questions regarding the transparency and reliability of the process by some stakeholders - a challenge not unique to South Africa. Several countries have developed lists of IAS without standardised risk assessment frameworks, for example,

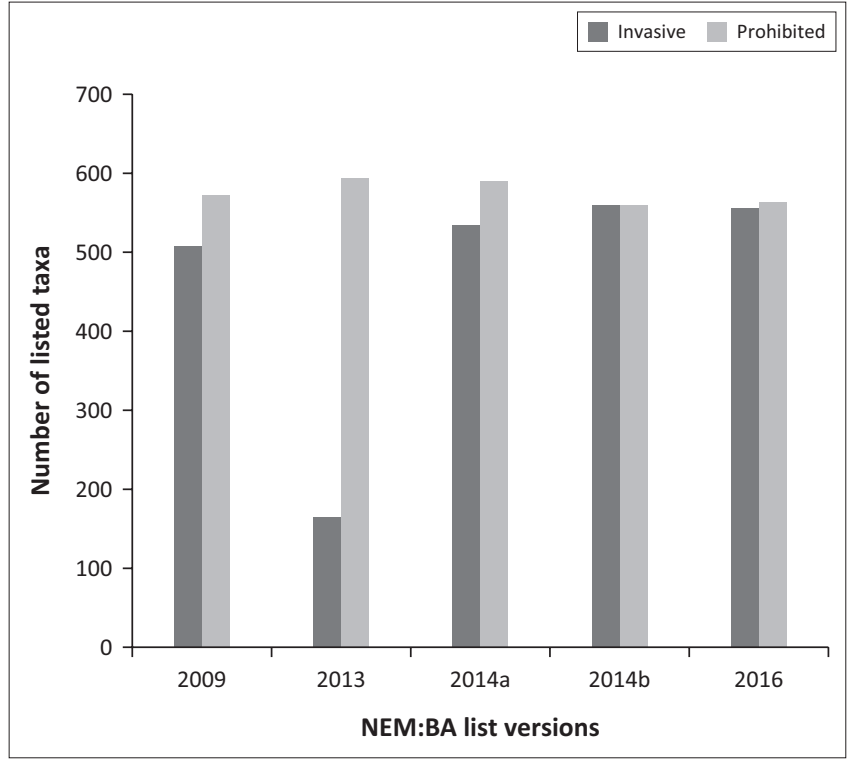

FIGURE 2: Total number of listed taxa for invasive and prohibited species in South Africa (a: 12 February 2014, b: 01 August 2014).

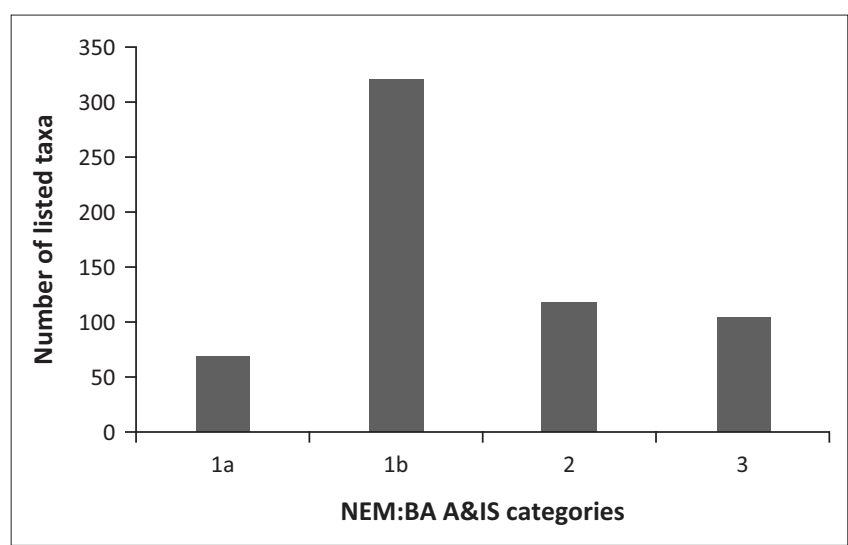

FIGURE 3: Number of taxa in the different legislative categories: Category 1a: invasive species that requires compulsory control; Category $1 \mathrm{~b}$ : invasive species that requires control by means of an invasive species management programme; Category 2: invasive species that can remain in your garden, but only with a permit; Category 3: invasive species that can remain in your garden. However, you cannot propagate or sell these species and must control them in your garden, for 2016 list.

Ukraine (Protopopova et al. 2006) and Austria (Essl \& Rabitsch 2004). Other common challenges to the development of the South African list included taxonomic uncertainties for some species, as was the case in other countries as well (Pyšek et al. 2008, 2013). Taxonomic uncertainties may lead to incorrect omission or inclusion of some species (Jacobs et al. 2017). The lack of information regarding the negative impacts of certain species further hinders invasive species listing across the world (Early et al. 2016; Verbrugge et al. 2012). Evaluation of the impact of many IAS is challenging because of gaps in the scientific understanding and lack of capacity.

Ineffective stakeholder engagement was a major issue faced in the development process. One of the major challenges encountered by the task team was public opposition against the listing of plant taxa, for example, Jacaranda mimosifolia, Cacti species and some Acacia species (Dickie et al. 2014; 
Novoa et al. 2016). This public opposition was fuelled by conflicts of interest between stakeholders surrounding the listing of species that have both economic and intrinsic benefits, but at the same time social and environmental costs (Dickie et al. 2014; Moshobane et al. in press; Novoa et al. 2015, 2016; Shackleton et al. 2016; Van Wilgen \& Richardson 2014; Zengeya et al. 2017). The initial listing of trout (Oncorhynchus mykiss) was a contentious issue, which ended up prolonging the listing process considerably as well as increasing the overall costs of the process (see Box 1) (Marr et al. 2017; Woodford et al. 2016). This led to the exclusion of trout in the 2014b list although it was re-included in 2016 as Category 2 species.

\section{Guidelines for future listing}

Despite several challenges faced with the list compilation and subsequently compliance, it still remains an effective regulatory tool for prohibiting new introductions, or placing restrictions on certain activities including breeding or planting of species and guiding management (García-deLomas \& Vilà 2015; McGeoch et al. 2012). These lists also form the basis of motivation for funding for management programmes and are therefore beneficial.

\section{Standardised methodology for listing}

Standardised procedures for listing are critical, and they must be evidence-based and transparent (Burgman 2004; Karasawa \& Nakata 2018; Keller \& Springborn 2014; Schmiedel et al. 2016; Vanderhoeven et al. 2015; Verbrugge et al. 2012). As expert opinions might differ and the fact that there are often a number of interested and affected parties or stakeholder groups (Burgman 2004; Latombe et al. 2017; Novoa et al. 2018), it is highly recommended to have standardised and transparent assessment tools (Genovesi et al. 2015). Verbrugge et al. (2012) proposed the use of a robust, transparent, science-based and evidence-based risk assessment. Furthermore, impact scoring can be used for already established invasive species (Nentwig et al. 2016; $\mathrm{Ou}$ et al. 2008) with frameworks already established for ecological and socio-economic factors (Bacher et al. 2018; Blackburn et al. 2014). There are numerous impact assessments tools, each with its own strengths and weaknesses (Gordon et al. 2012; Nishida et al. 2009; Pheloung, Williams \& Halloy 1999; Rumlerová et al. 2016). Several countries have developed or adopted some kind of standardised frameworks for risk assessment, often based on the Australian Weed Risk Assessment (Andreu \& Villa 2010; Copp et al. 2009; Essl et al. 2011; Gollasch \& Nehring 2006; Roy et al. 2019). Successful application of risk assessment has benefits for both the environment and economy through prevention of species introductions with high impact potential (Keller, Frang \& Lodge 2008; Keller, Lodge \& Finnoff 2007; Pimentel 2009).

\section{Stakeholder engagement}

Stakeholder engagement is crucial when working with environmental management issues (Colvin, Witt \&
Lacey 2016; Reed 2008; Reed et al. 2009; Shackleton et al. 2019), and it is particularly important when dealing with conflict species (Novoa et al. 2018; Zengeya et al. 2017). It can help to build buy-in, cooperation and reduce contentious issues (Panten et al. 2018; Rollason et al. 2018; Ward et al. 2018).

In future listing, it will be crucial to identify and work in close consultation with all relevant stakeholders to avoid conflicts in the development and revision of invasive alien species lists. A framework to guide engagement process has recently been developed (Novoa et al. 2018). Notably, Novoa et al. (2015) showed that conflict can be managed satisfactorily though successful engagement with different parties. A plan and evidence to reconcile existing conflicts of interest, pertaining to listed species that have both negative impacts on ecosystem and high commercial value, are needed and could be based on cost-benefit assessments or livelihood assessments (De Wit, Crookes \& van Wilgen 2001; Ngorima \& Shackleton 2019; Zengeya et al. 2017). Sometimes, control of species with intrinsic value has led to public outcry and opposition against regulatory measures (Estévez et al. 2015). This is because in South Africa and elsewhere, certain species trigger public responses based on societal values. This includes moralistic values for Anas platyrhynchos (mallard duck) in central Cape Town, where animal rights groups opposed their eradication (Gaertner et al. 2016), and iconic and aesthetic values of Jacaranda mimosifolia (jacaranda) trees in central Pretoria (Dickie et al. 2014; Kasrils 2001). Similarly, stakeholders were very opposed to the listing of rainbow trout, which led to protracted discussions between them and the DEA (see Box 1), and which was mainly based on the potential loss of recreational value. Public opposition to management of IAS not unique to South Africa is shown in a study by Crowley, Hinchliffe and McDonald (2018). This highlights the need to better understand stakeholder knowledge, perceptions and world views and develop appropriate engagement and awareness campaigns (Kull et al. 2019; Shackleton et al. 2019b).

Nationwide stakeholder engagements have been conducted, particularly with the nursery industry, to settle issues arising from the listing of Cactaceae. This resulted in good collaboration and a widely accepted national plan to manage this plant family (Kaplan et al. 2017; Novoa et al. 2015, 2016), leading to win-win solutions for different groups of actors. Given the complexity underpinning values and risk

BOX 1: Rainbow trout (Oncorhynchus mykiss) as an example of a conflict species. Rainbow trout is a salmonid fish native to the Pacific northwest of North America. It was introduced in many parts of the world. It has since spread and established globally and ranked as the worst global invasive freshwater fish. Despite documented negative impact on various scales in South Africa and around the world, regulating trout is still challenging because of the interest of various groups, with arguments ranging from viability of aquaculture to sport fisheries. There have been numerous stakeholder engagement meetings to discuss conflict species, particularly trout. To this end conflict management and delimitation are still indefinite as there are still underlying issues to be resolved.

Source: Silvestre, E.G. \& Gabrielyan, B.K., 2001, 'An annotated checklist of freshwater fishes of Armenia', Fisheries Section of the Network of Tropical Aquaculture and Fisheries Professionals 24, 23-29; and, Weyl, O.LF., Ellender, B., Ivey, P., Jackson, M.C., Tweddle, D., Professionals 24, 23-29; and, Weyl, O.LF., Ellender, B., Ivey, P., Jackson, M.C., Tweddle, D.,
Wasserman, R.J. et al., 2017, Brown Trout introductions, establishment, current status, impacts and conflicts, Brown Trout, John Wiley \& Sons, Ltd, Chichester, pp. 623-639 
BOX 2: The Alien Species Risk Analysis Review Panel.

The Alien Species Risk Analysis Review Panel (ASRARP) was inaugurated in South Africa in November 2016. The panel was established per agreement between SANBI and the Biosecurity Directorate of the Department of Environmental Affairs (DEA). The role of the panel is to (but not limited to) review the risk analyses of regulated species, provide scientific guidance and ensure scientific analys of the risk assessments carried out under the auspices of the scientific (a) regulations. The panel has no executive or decision-making powers, but is th The Ali the Department of Environment, Forestry and Fisheries.

The Alien Speies Risk Analysis Review Panel further provides oversight on

partnership with national and provincial government departments as well as relevant stakeholders.

perception, it is challenging to implement regulations and stakeholder engagement as required continuously (Kellert 1993; Shackleton et al. 2016).

In contrast, contentious issues also arose between different parties as it was evident that some of the taxa on the NEM:BA IAS list were included because of their impacts and invasive statuses in other parts of the world, because the listing was purely based on expert opinion, and because and many other stakeholders have alternative understanding and world views to these experts. However, processes driven by a scientific expert panel's recommendations that have been practiced and proven as an effective way of listing species for legislative regulations in other regions of the world (Lukasiewicz, Pittock \& Finlayson 2016; Nishida et al. 2009; Pergl et al. 2016; Schmiedel et al. 2016) and investigation into these success cases are needed (see Box 2). Given that the management of biodiversity and natural resources is intertwined with humans and society (Rotherham \& Lambert 2011), successful management requires societal engagement and transparency (Sawchuk et al. 2015; Stankey \& Shindler 2006), which could lead to lower public opposition and broader awareness (McNeely et al. 2005).

\section{Specific recommendations for the future development and implementation of lists}

Lastly, we make a few specific recommendations for improving the revision of lists and uptake of the NEM:BA regulations linked to the current list.

\section{The role of leadership and institutions}

There is a need to establish a national forum that will provide supervision on all affairs of IAS regulation and listing. Most importantly, one goal of this forum should be to develop a well-defined listing process that provides for public participation and that is standardised as well as transparent (Novoa et al. 2018). This needs to be driven by a champion to ensure success and continuity.

\section{The role of collaboration and engagement}

Engagement and collaboration can effectively solve issues and lead to win-win solutions, building of trust, co-development of solutions and social learning among actors (Novoa et al. 2018; Shackleton et al. 2019a). This can help to transcend boundaries and promote true transdisciplinary collaboration relating to policy and management (Booy et al. 2017).

\section{Educate the public about invasive alien species regulations and management}

The success of IAS management planning and implementation is intertwined with public buy-in; it is therefore critical to educate and engage with the public (Novoa et al. 2018; Shackleton et al. 2019a). Education campaigns elsewhere in the world have been successful in promoting awareness and compliance (Cole, Keller \& Garbach 2019). In South Africa, promoting further awareness of the impacts on IAS as well as the regulations and lists will be important, as generally knowledge of the topic is poor (Shackleton \& Shackleton 2016). Such awareness raising and education could increase buy-in, but information on approaches on how best to do this is still needed and there is currently a knowledge gap.

\section{Conclusion}

This article provides insights into the IAS listing process in South Africa and highlights some shortcomings as well as opportunities. Expert workshops and public engagement approaches for listing of species have been useful with a resultant national list of IAS. Although the process was fruitful, there is still room for improvement, particularly with the alignment of the international recommendation for listing of alien and invasive species. We particularly discuss some recommendations relating to standardising the listing process and engaging and educating stakeholders.

\section{Acknowledgements}

The South African National Department of Environment Forestry and Fisheries, through its funding of the South African National Biodiversity Institute's Biological Invasions Directorate (BID), is acknowledged. The authors appreciate Lesley Henderson, Ingrid Nanni and the BID team for their contributions towards the preparation of this manuscript.

\section{Competing interests}

The authors declare that they have no financial or personal relationships that may have inappropriately influenced them in writing this article.

\section{Authors' contributions}

M.C.M. was responsible for writing for the manuscript. M.M. assisted in the compilation of the lists of IAS from the Government Gazette. S.A.-A. and R.S. provided input for this manuscript.

\section{Ethical considerations}

This article followed all ethical standards for research without direct contact with human or animal subjects.

\section{Data availability statement}

Data sharing is not applicable to this article as no new data were created or analysed in this study. 


\section{Disclaimer}

This article represents the opinions of the authors and is the product of professional research. It is not meant to represent the position or opinions of the employers or its members, nor the official position of any staff members. The funding agencies do not accept any liability in this regard.

\section{References}

Andreu, J. \& Vilà, M., 2010, 'Risk analysis of potential invasive plants in Spain', Journa for Nature Conservation 18(1), 34-44. https://doi.org/10.1016/j.jnc.2009.02.002

Anonymous, 2008, Task team workshop minutes, DEA AIS Task team. Biodiversity Act regulations for alien and invasive species minutes of a task-team meeting.

Bacher, S., Blackburn, T. M., Essl, F., Genovesi, P., Heikkilä, J., Jeschke, J. M. et al., 2018, 'Socio-economic impact classification of alien taxa (SEICAT)', Methods in Ecology and Evolution 9(1), 159-168. https://doi.org/10.1111/2041-210X.12844

Blackburn, T.M., Essl, F., Evans, T., Hulme, P.E., Jeschke, J.M., Kühn, I. et al., 2014, 'A unified classification of alien species based on the magnitude of their environmental impacts', PLOS Biology 12(5), p.e1001850.

Burgman, M., 2004, 'Expert frailties in conservation risk assessment and listing decisions', in P. Hutchings, D. Lunney \& C. Dickman (eds.), Threatened species legislation : Is it just an Act?, pp. 20-29, Royal Zoological Society of New South Wales, Mosman.

Booy, O., Mill, A. C., Roy, H. E., Hiley, A., Moore, N., Robertson, P. et al., 2017, 'Risk management to prioritise the eradication of new and emerging invasive non-
native species', Biological Invasions 19(8), 2401-2417. https://doi.org/10.1007/ s10530-017-1451-z

Butchart, S.H.M., Walpole, M., Collen, B., van Strien, A., Scharlemann, J.P.W., Almond R.E.A. et al., 2010, 'Global biodiversity: Indicators of recent declines', Science 328(5982), 1164-1168. https://doi.org/10.1126/science.1187512

Clark, T. \& Wallace, R., 2002, 'Understanding the human factor in endangered species recovery: An introduction to human social process', Endangered Species Update 15, 2-9.

Colvin, R.M., Witt, G.B. \& Lacey, J., 2016, 'Approaches to identifying stakeholders in environmental management: Insights from practitioners to go beyond the in environmental management: Insights from practitioners to go beyond the
"usual suspects"', Land Use Policy 52, 266-276. https://doi.org/10.1016/j. "usual suspects"', Land
landusepol.2015.12.032

Cole, E., Keller, R.P. \& Garbach, K., 2019, 'Risk of invasive species spread by recreational boaters remains high despite widespread adoption of conservation behaviors', Journal of Environmental Management 229, 112-119.

Copp, G.H., Vilizzi, L., Mumford, J., Fenwick, G.V., Godard, M.J. \& Gozlan, R.E., 2009, 'Calibration of FISK, an invasiveness screening tool for nonnative freshwater fishes', Risk Analysis 29(3), 457-467. https://doi.org/10.1111/j.1539-6924.2008.01159.x

Crowley, S.L., Hinchliffe, S. \& McDonald, R.A., 2019, 'The parakeet protectors: Understanding opposition to introduced species management', Journal of Environmental Management 229, 120-132. https://doi.org/10.1016/J.JENVMAN. 2017.11.036

de Wit, M.P., Crookes, D.J. \& van Wilgen, B.W., 2001, 'Conflicts of interest in environmental management: Estimating the costs and benefits of a tree invasion', Biological Invasions 3(2), 167-178. https://doi.org/10.1023/A:1014563702261

Dickie, I.A., Bennett, B.M., Burrows, L.E., Nuñez, M.A., Peltzer, D.A., Porté, A. et al., 2014, 'Conflicting values: Ecosystem services and invasive tree management', 2014, 'Conflicting values: Ecosystem services and invasive tree management',
Biological Invasions 16(3), 705-719. https://doi.org/10.1007/s10530-013-0609-6

Early, R., Bradley, B.A., Dukes, J.S., Lawler, J.J., Olden, J.D., Blumenthal, D.M. et al. 2016, 'Global threats from invasive alien species in the twenty-first century and national response capacities', Nature Communications 7, 12485. https://doi. org/10.1038/ncomms12485

Essl, F., Nehring, S., Klingenstein, F., Milasowszky, N., Nowack, C. \& Rabitsch, W., 2011 'Review of risk assessment systems of IAS in Europe and introducing the GermanAustrian Black List Information System GABLIS', Journal for Nature Conservation 19(6), 339-350. https://doi.org/10.1016/j.jnc.2011.08.005

Essl, F. \& Rabitsch, W., 2004, Austrian action plan on invasive alien species, Vienna.

Estévez, R.A., Anderson, C.B., Pizarro, J.C. \& Burgman, M.A., 2015, 'Clarifying values, risk perceptions, and attitudes to resolve or avoid social conflicts in invasive species
management', Conservation Biology 29(1), 19-30. https://doi.org/10.1111/cobi.12359

Faulkner, K.T., Robertson, M.P., Rouget, M. \& Wilson, J.R.U., 2014, 'A simple, rapid methodology for developing invasive species watch lists', Biological Conservation 179, 25-32. https://doi.org/10.1016/j.biocon.2014.08.014

Faulkner, K.T., Robertson, M.P., Rouget, M. \& Wilson, J.R.U., 2016, 'Understanding and managing the introduction pathways of alien taxa: South Africa as a case study", Biological Invasions 18(1), 73-87. https://doi.org/10.1007/s10530-015-0990-4

Gaertner, M., Larson, B.M.H., Irlich, U.M., Holmes, P.M., Stafford, L., van Wilgen, B.W. et al., 2016, 'Managing invasive species in cities: A framework from Cape Town, South Africa', Landscape and Urban Planning 151, 1-9. https://doi.org/10.1016/j. landurbplan.2016.03.010

García-de-Lomas, J. \& Vilà, M., 2015, 'Lists of harmful alien organisms: Are the national regulations adapted to the global world?', Biological Invasions 17(11), 3081-3091. https://doi.org/10.1007/s10530-015-0939-7

Genovesi, P., Carboneras, C., Vilà, M. \& Walton, P., 2015, 'EU adopts innovative legislation on invasive species: A step towards a global response to biological invasions?', Biological Invasions, Springer International Publishing 17(5), 1307-1311. https://doi.org/10.1007/s10530-014-0817-8
Gollasch, S. \& Nehring, S., 2006, 'National checklist for aquatic alien species in Germany', Aquatic Invasions 1(4), 245-269. https://doi.org/10.3391/ai.2006.1.4.8

Gordon, D.R., Gantz, C.A., Jerde, C.L., Chadderton, W.L., Keller, R.P. \& Champion, P.D., 2012, 'Weed risk assessment for aquatic plants: Modification of a New Zealand system for the United States', PLoS One 7(7), e40031. https://doi.org/10.1371/ journal.pone. 0040031

Henderson, L. \& Wilson, J.R.U., 2017, 'Changes in the composition and distribution of alien plants in South Africa: An update from the Southern African Plant Invaders Atlas', Bothalia 47(2), 26. https://doi.org/10.4102/abc.v47i2.2172

Jacobs, L., Wilson, J., Lepschi, B. \& Richardson, D., 2017, 'Quantifying errors and omissions in alien species lists: The introduction status of Melaleuca species in South Africa as a case study', NeoBiota 32, 89-105. https://doi.org/10.3897/neobiota.32.9842

Kaplan, H., Wilson, J.R., Klein, H., Henderson, L., Zimmermann, H.G., Manyama, P. et al., 2017. 'A proposed national strategic framework for the management of Cactaceae in South Africa', Bothalia-African Biodiversity \& Conservation 47(2), $1-12$.

Karasawa, S. \& Nakata, K., 2018, 'Invasion stages and potential distributions of seven exotic terrestrial isopods in Japan', BioRisk 13, 53-76. https://doi.org/10.3897/ biorisk.13.23514

Kasrils, R., 2001, Jacaranda - Xenophobia in the name of environment management? Green Gold, viewed 27 February 2017, from http://www.stratek.co.za/.\%5Carch ive $\% 5$ Cronniekasrils.html

Keller, R.P., Frang, K. \& Lodge, D.M., 2008, 'Preventing the spread of invasive species: Economic benefits of intervention guided by ecological predictions', Conservation Biology 22(1), 80-88. https://doi.org/10.1111/j.1523-1739.2007.00811.x

Keller, R.P., Lodge, D.M. \& Finnoff, D.C., 2007, 'Risk assessment for invasive species produces net bioeconomic benefits', Proceedings of the National Academy of Sciences of the United States of America 104(1), 203-237. https://doi. org/10.1073/pnas.0605787104

Keller, R.P. \& Springborn, M.R., 2014, 'Closing the screen door to new invasions', Conservation Letters 7(3), 285-292.

Kellert, S.R., 1993, 'Values and perceptions of invertebrates', Conservation Biology 7(4), 845-855. https://doi.org/10.1046/j.1523-1739.1993.740845.x

Kil, J., Mun, S. \& Kim, C., 2015, 'Risk assessment tools for invasive alien species in Japan and Europe', Ecology and Resilient Infrastructure 2(3), 191-197. https://doi. org/10.17820/eri.2015.2.3.191

Kolar, C.S. \& Lodge, D.M., 2001, 'Progress in invasion biology: Predicting invaders', Trends in Ecology \& Evolution 16(4), 199-204. https://doi.org/10.1016/S0169Trends in Ecology
$5347(01) 02101-2$

Kull, C.A., Harimanana, S.L., Andrianoro, A.R. \& Rajoelison, L.G., 2019, 'Divergent perceptions of the 'neo-Australian'forests of lowland eastern Madagascar: Invasions, transitions, and livelihoods', Journal of Environmental Management 229, 48-56.

Latombe, G., Pyšek, P., Jeschke, J.M., Blackburn, T.M., Bacher, S., Capinha, C. et al., 2017, 'A vision for global monitoring of biological invasions', Biological Conservation 213, 295-308. https://doi.org/10.1016/j.biocon.2016.06.013

Lukasiewicz, A., Pittock, J. \& Finlayson, M., 2016, 'Institutional challenges of adopting ecosystem-based adaptation to climate change', Regional Environmental Change 16(2), 487-499. https://doi.org/10.1007/s10113-015-0765-6

Lupi, F., Hoehn, J.P. \& Christie, G.C., 2003, 'Using an economic model of recreational fishing to evaluate the benefits of sea Lamprey (Petromyzon marinus) control on the St. Marys River', Journal of Great Lakes Research 29, 742-754. https://doi. org/10.1016/S0380-1330(03)70528-0

Marr, S.M., Ellender, B.R., Woodford, D.J., Alexander, M.E., Wasserman, R.J., Ivey, P. et al., 2017, 'Evaluating invasion risk for freshwater fishes in South Africa', Bothalia 47(2), 1-10. https://doi.org/10.4102/abc.v47i2.2177

McGeoch, M.A., Butchart, S.H.M., Spear, D., Marais, E., Kleynhans, E.J., Symes, A. et al., 2010, 'Global indicators of biological invasion: Species numbers, biodiversity impact and policy responses', Diversity and Distributions 16(1), 95-108. https:// doi.org/10.1111/j.1472-4642.2009.00633.x

McGeoch, M.A., Spear, D., Kleynhans, E.J. \& Marais, E., 2012, 'Uncertainty in invasive alien species listing', Ecological Applications: A Publication of the Ecological Society of America 22(3), 959-71.

McNeely, J.A., Mooney, H.A., Neville, L.E., Schei, P.J. \& Waage, J.K., 2005, 'A global strategy on invasive alien species: Synthesis and ten strategic elements', in H.A. Mooney, R.N. Mack, J.A. McNeely, L.E. Neville, P.J. Schei \& J.K. Waage (eds.), Invasive alien species: A new synthesis, pp. 332-345, Island Press, Washington, DC.

Morrison, T.H., McAlpine, C., Rhodes, J.R., Peterson, A. \& Schmidt, P., 2010, 'Back to the future? Planning for environmental outcomes and the new caring for our country program', Australian Geographer 41(4), 521-538. https://doi.org/10.108 $0 / 00049182.2010 .519763$

Moshobane, M.C., Nnzeru, L.N., Nelukalo, K. \& Mothapo, N.P., (in press), Patterns of permit requests and issuance regulated alien and invasive species in South Africa for the period 2015-2018.

Nentwig, W., Bacher, S., Pyšek, P., Vilà, M. \& Kumschick, S., 2016, 'The generic impact scoring system GISS: A standardized tool to quantify the impacts of alien species' Environmental Monitoring and Assessment 188(5), 315. https://doi.org/10.1007/ s10661-016-5321-4

Ngorima, A. \& Shackleton, C.M., 2019, 'Livelihood benefits and costs from an invasive alien tree Acacia dealbata to rural communities in the Eastern Cape, South Africa', Journal of Environmental Management 229, 158-165. https://doi.org/10.1016/J. JENVMAN.2018.05.077

Nishida, T., Yamashita, N., Asai, M., Kurokawa, S., Enomoto, T., Pheloung, P.C. et al. 2009, 'Developing a pre-entry weed risk assessment system for use in Japan' Biological Invasions 11(6), 1319-1333. https://doi.org/10.1007/s10530-008-9340-0 
Novoa, A., Kaplan, H., Kumschick, S., Wilson, J.R.U. \& Richardson, D.M., 2015, 'Soft touch or heavy hand? Legislative approaches for preventing invasions: Insights from Cacti in South Africa', Invasive Plant Science and Management 8(3), 307-316. https://doi.org/10.1614/IPSM-D-14-00073.1

Novoa, A., Kaplan, H., Wilson, J.R.U. \& Richardson, D.M., 2016, 'Resolving a prickly situation: Involving stakeholders in invasive cactus management in South Africa', Environmental Management 575, 998-1008. https://doi.org/10.1007/s00267015-0645-3

Novoa, A., Shackleton, R., Canavan, S., Cybèle, C., Davies, S.J., Dehnen-Schmutz, K. et al., 2018, 'A framework for engaging stakeholders on the management of alien species', Journal of Environmental Management 205, 286-297. https://doi. org/10.1016/j.jenvman.2017.09.059

Ou, J., Lu, C. \& O’Toole, D.K., 2008, 'A risk assessment system for alien plant bioinvasion in Xiamen, China', Journal of Environmental Sciences 208, 989-997. https://doi.org/10.1016/S1001-0742(08)62198-1

Panten, K., van Heel, B.F., Fliervoet, J.M. \& van den Born, R.J.G., 2018, 'Cross-border collaboration in river management: Views on participation in a Dutch-German case study', Water Resources Management 3212, 4063-4078. https://doi. org/10.1007/s11269-018-2039-9

Pejchar, L. \& Mooney, H.A., 2009, 'Invasive species, ecosystem services and human well-being', Trends in Ecology \& Evolution 24(9), 497-504. https://doi. org/10.1016/j.tree.2009.03.016

Pergl, J., Sádlo, J., Petrusek, A., Laštůvka, Z., Musil, J., Perglová, I. et al., 2016, 'Black grey and watch lists of alien species in the Czech Republic based on environmental impacts and management strategy', NeoBiota 28, 1-37. https://doi.org/10.3897/ neobiota.28.4824

Perry, D. \& Perry, G., 2008, 'Improving interactions between animal rights groups and conservation biologists', Conservation Biology 22(1), 27-35. https://doi. org/10.1111/j.1523-1739.2007.00845.x

Pheloung, P.C., Williams, P.A. \& Halloy, S.R., 1999, 'A weed risk assessment model for use as a biosecurity tool evaluating plant introductions', Journal of Environmental Management 57(4), 239-251. https://doi.org/10.1006/jema.1999.0297

Pimentel, D., 2009, 'Know your enemy bioeconomics of invasive species: Integrating ecology, economics, policy, and management', R.P. Keller, D.M. Lodge, M.A. Lewis \& J.F. Shogren (eds.), Oxford University Press, New York, BioScience 59(11), 1002-1003.

Possingham, H.P., Andelman, S.J., Burgman, M.A., Medellín, R.A., Master, L.L. \& Keith, D.A., 2002, 'Limits to the use of threatened species lists', Trends in Ecology \& Evolution 17(11), 503-507. https://doi.org/10.1016/S01695347(02)02614-9

Protopopova, V.V., Shevera, M.V. \& Mosyakin, S.L., 2006, 'Deliberate and unintentional introduction of invasive weeds: A case study of the alien flora of Ukraine', Euphytica 148(1-2), 17-33. https://doi.org/10.1007/s10681-006-5938-4

Pyšek, P., Hulme, P.E., Meyerson, L.A., Smith, G.F., Boatwright, J.S., Crouch, N.R. et al., 2013, 'Hitting the right target: Taxonomic challenges for, and of, plant invasions', AOB PLANTS 5, plt042.

Pyšek, P., Richardson, D.M., Pergl, J., Jarošík, V., Sixtová, Z. \& Weber, E., 2008 'Geographical and taxonomic biases in invasion ecology', Trends in Ecology \& Evolution 23(5), 237-244. https://doi.org/10.1016/j.tree.2008.02.002

Reed, M.S., 2008, 'Stakeholder participation for environmental management: A literature review', Biological Conservation 141(10), 2417-2431. https://doi. org/10.1016/j.biocon.2008.07.014

Reed, M.S., Graves, A., Dandy, N., Posthumus, H., Hubacek, K., Morris, J. et al., 2009 'Who's in and why? A typology of stakeholder analysis methods for natura resource management', Journal of Environmental Management, Academic Press resource management', Journal of Environmental Management, A
90(5), 1933-1949. https://doi.org/10.1016/j.jenvman.2009.01.001

Rollason, E., Bracken, L.J., Hardy, R.J. \& Large, A.R.G., 2018, 'Evaluating the success of public participation in integrated catchment management', Journal of Environmental Management 228, 267-278. https://doi.org/10.1016/j. of Environmental

Roy, H.E., Brodie, J., Bacher, S., Essl, F., David, T.A., John, C.A. et al., 2019, 'Developing a list of invasive alien species likely to threaten biodiversity and ecosystems in the European Union', Global Change Biology 25(1), 1032-1048. https://doi. org/10.1111/gcb.14527
Rotherham, I. D. \& Lambert, R.A. (eds.), 2011, Invasive and introduced plants and animals: Human perceptions, attitudes and approaches to management, Earthscan, New York.

Rumlerová, Z., Vilà, M., Pergl, J., Nentwig, W. \& Pyšek, P., 2016, 'Scoring environmental and socioeconomic impacts of alien plants invasive in Europe', Biological Invasions 18(12), 3697-3711. https://doi.org/10.1007/s10530-016-1259-2

Sawchuk, J.H., Beaudreau, A.H., Tonnes, D. \& Fluharty, D., 2015, 'Using stakeholder engagement to inform endangered species management and improve conservation', Marine Policy 54, 98-107. https://doi.org/10.1016/j. marpol.2014.12.014

Schmiedel, D., Wilhelm, E.-G., Roth, M., Scheibner, C., Nehring, S. \& Winter, S., 2016, 'Evaluation system for management measures of invasive alien species', Biodiversity and Conservation 25(2), 357-374. https://doi.org/10.1007/s10531016-1054-5

Shackleton, R.T., Adriaens, T., Brundu, G., Dehnen-Schmutz, K., Estévez, R.A., Fried, J. et al., 2019, 'Stakeholder engagement in the study and management of invasive alien species', Journal of Environmental Management 229, 88-101. https://doi. org/10.1016/j.jenvman.2018.04.044

Shackleton, R.T., Le Maitre, D.C., van Wilgen, B.W. \& Richardson, D.M., 2016 'Identifying barriers to effective management of widespread invasive alien trees:
Prosopis species mesquite in South Africa as a case study', Global Environmental Prosopis species mesquite in South Africa as a case study', Global Environr
Change 38, 183-194. https://doi.org/10.1016/j.gloenvcha.2016.03.012

Shackleton, R.T., Richardson, D.M., Shackleton, C.M., Bennett, B., Crowley, S.L. Dehnen-Schmutz, K. et al., 2019, 'Explaining people's perceptions of invasive alien species: A conceptual framework', Journal of Environmental Management 229, species:

Shackleton, C.M. \& Shackleton, R.T., 2016, 'Knowledge, perceptions and willingness to control designated invasive tree species in urban household gardens in South Africa', Biological Invasions 18(6), 1599-1609.

Silvestre, E.G. \& Gabrielyan, B.K., 2001, 'An annotated checklist of freshwater fishes of Armenia', Fisheries Section of the Network of Tropical Aquaculture and Fisheries Professionals 24, 23-29.

Simberloff, D., 2003, 'How much information on population biology is needed to manage introduced species?', Conservation Biology 17(1), 83-92. https://doi. org/10.1046/j.1523-1739.2003.02028.x

Stankey, G.H. \& Shindler, B., 2006, 'Formation of social acceptability judgments and their implications for management of rare and little-known species', Conservation Biology: The Journal of the Society for Conservation Biology 20(1), 28-37. https:// doi.org/10.1111/j.1523-1739.2005.00298.x

UNEP CBD (2000) Convention on Biological Diversity, 2002, Decisions adopted by the conference of the parties to the convention on biological diversity at its sixth meeting, UNEP/CBD/COP/6/23.

Vanderhoeven, S., Adriaens, T. Bram, D., Gossum, H. Van, Vandegehuchte, M. Verreycken, $\mathrm{H}$. et al., 2015, 'A science-based approach to tackle invasive alien species in Belgium - the role of the ISEIA protocol and the Harmonia information system as decision support tools', Management of Biological Invasions 6(2), 197-208.

Verbrugge, L.N.H., van der Velde, G., Jan Hendriks, A., Verreycken, H. \& Leuven, R.S.E.W., 2012, 'Risk classifications of aquatic non-native species: Application of contemporary European assessment protocols in different biogeographical settings', Aquatic Invasions 7(1), 49-58. https://doi.org/10.3391/ai.2012.7.1.006

Ward, C., Stringer, L.C. \& Holmes, G., 2018, 'Protected area co-management and perceived livelihood impacts', Journal of Environmental Management 228, 1-12. https://doi.org/10.1016/j.jenvman.2018.09.018

Weyl, O.LF., Ellender, B., Ivey, P., Jackson, M.C., Tweddle, D., Wasserman, R.J. et al., 2017, Brown Trout introductions, establishment, current status, impacts and conflicts, Brown Trout, John Wiley \& Sons, Ltd, Chichester, pp. 623-639.

Van Wilgen, B.W. \& Richardson, D.M., 2014, 'Challenges and trade-offs in the management of invasive alien trees', Biological Invasions 16(3), 721-734.

Woodford, D.J., Richardson, D.M., Maclsaac, H.J., Mandrak, N.E., van Wilgen, B.W. Wilson, J.R.U. et al., 2016, 'Confronting the wicked problem of managing biological invasions', NeoBiota 31, 63-86. https://doi.org/10.3897/neobiota.31.10038

Zengeya, T., Ivey, P., Woodford, D.J., Weyl, O., Novoa, A., Shackleton, R. et al., 2017, 'Managing conflict-generating invasive species in South Africa: Challenges and trade-offs', Bothalia 47(2), 1-11. https://doi.org/10.4102/abc.v47i2.2160 


\section{Appendix 1: List of organisations represented or participated in the listing meetings 2006.}

1. South African Pet Trade Association

2. Gauteng Nature Conservation

3. South African National Biodiversity Institute

4. CapeNature

5. Port Elizabeth Bayworld

6. Gauteng provincial government

7. Free State Department of Tourism, Environmental \& Economic Affairs

8. North West Department of Agriculture, Conservation, Environment and Rural Development

9. Stellenbosch University

10. Department of Environment, Forestry and Fisheries

11. South African Hunters and Game Conservation Association

12. Wildlife Ranching South Africa

13. Malanseuns Ltd Pty

14. Northern Cape Department of Tourism, Environment \& Conservation

15. Working for Water

16. Free State provincial government

17. Ezemvelo KZN Wildlife

18. Legal drafter of the regulations

19. Facilitator, Sustainability Matters

20. University of South Africa

21. Department of Agriculture (National)

22. Agricultural Research Council

\section{Appendix 2}

TABLE 1-A2: Analysis of the current list and issues arising from the list.

\begin{tabular}{|c|c|c|c|c|}
\hline Issue & Description & \# taxa & Examples & Recommendation \\
\hline Sterility & $\begin{array}{l}\text { Sterile cultivars and hybrids of certain } \\
\text { species are not listed. This is } \\
\text { problematic as it is not known how to } \\
\text { distinguish sterile from non-sterile } \\
\text { cultivars, and it is not clear if sterile } \\
\text { hybrids or all hybrids are exempted. It is } \\
\text { also not clear how stable sterility is, } \\
\text { both in captivity and in the wild. }\end{array}$ & List 1 Species 24 & $\begin{array}{l}\text { Ageratum houstonianum is listed as } \\
1 \mathrm{~b} \text {, but sterile cultivars or hybrids are } \\
\text { not listed. }\end{array}$ & $\begin{array}{l}\text { Some of the taxa for which sterile cultivars and } \\
\text { hybrids are exempted are known to be highly invasive } \\
\text { and damaging. As long as the mechanisms for sterility } \\
\text { and the reversibility of such sterility are not known, } \\
\text { these should not be exempted under any } \\
\text { circumstance. }\end{array}$ \\
\hline Other cultivars & $\begin{array}{l}\text { Spineless cultivars, specific cultivars and } \\
\text { selections are not listed. It is, however, } \\
\text { not clear how stable these varieties and } \\
\text { cultivars are in the wild. }\end{array}$ & List 1 Species 122 & $\begin{array}{l}\text { Duranta erecta is listed under various } \\
\text { categories in various parts of the } \\
\text { country, but a certain cultivar } \\
\text { ('Sheena's Gold') is not listed. } \\
\text { Opuntia ficus-indica is listed as } 1 \mathrm{~b}, \\
\text { but spineless cultivars and selections } \\
\text { are not listed. }\end{array}$ & $\begin{array}{l}\text { It is questionable whether spinelessness is stable as } \\
\text { spiny versions have been observed in the wild in } \\
\text { previously spineless populations of some species. } \\
\text { As long as the irreversibility of spinelessness is not } \\
\text { proven, these cultivars should not be exempted. } \\
\text { Furthermore, it is not clear what makes some cultivars } \\
\text { less invasive or damaging than others. Unless this is } \\
\text { proven, the cultivars should be listed the same as the } \\
\text { parent species. }\end{array}$ \\
\hline Hybrids & $\begin{array}{l}\text { General mention of hybrids or specific } \\
\text { species combinations listed. }\end{array}$ & List 5 Species 4 & $\begin{array}{l}\text { All hybrids of mammal species or } \\
\text { sub-species listed are Category } 1 \mathrm{a}, \\
\text { with one exception. } \\
\text { Unless otherwise listed, all hybrids } \\
\text { between indigenous and introduced } \\
\text { species of reptiles and amphibians are } \\
\text { listed as Category } 1 \mathrm{~b} \text {. } \\
\text { Bitis gabonica } \times \text { Bitis sp. are listed as } 1 \mathrm{~b} \text {. }\end{array}$ & $\begin{array}{l}\text { Many hybrids are only distinguishable from their } \\
\text { parents using genetic tests. It is therefore difficult to } \\
\text { control only hybrids. }\end{array}$ \\
\hline $\begin{array}{l}\text { Listing of } \\
\text { multiple species }\end{array}$ & $\begin{array}{l}\text { Some taxa are not listed on species } \\
\text { level, but at genus, family or order level. } \\
\text { Certain higher level taxa listed also } \\
\text { contain species native to South Africa, } \\
\text { which cannot and must not be listed } \\
\text { under these regulations. Other species } \\
\text { within these taxa are not present in the } \\
\text { country (yet) and can therefore also not } \\
\text { be listed under the alien and invasive } \\
\text { species lists. }\end{array}$ & List 6 Species 2 & $\begin{array}{l}\text { Dendrobatidae are listed as the whole } \\
\text { family under Category } 2 .\end{array}$ & $\begin{array}{l}\text { Species which are native to South Africa or certain parts } \\
\text { of the country should not be listed in the respective } \\
\text { native areas. Furthermore, species which are not present } \\
\text { in the country should be listed under the prohibited list if } \\
\text { they are shown to be a risk to South Africa. Therefore, the } \\
\text { listing of higher taxa only makes sense for cryptic species } \\
\text { for which taxonomy on a species level is not well sorted, } \\
\text { or for which identification to species level is not easily } \\
\text { possible. For all other taxa, listing on species level is more } \\
\text { useful. Furthermore, the heading of the taxa listing } \\
\text { column reads 'Species', which leads to the impression } \\
\text { that only species-level listings are found there. }\end{array}$ \\
\hline $\begin{array}{l}\text { Listing of sub- } \\
\text { species }\end{array}$ & $\begin{array}{l}\text { Some taxa are listed on a sub-species } \\
\text { level. }\end{array}$ & List 5 Species 7 & $\begin{array}{l}\text { Aepyceros melampus petersi is listed as } \\
\text { Category } 2 . \\
\text { Bitis gabonica rhinoceros is listed as } \\
\text { Category } 2 \text { in KwaZulu-Natal, } \\
\text { Mpumalanga, Eastern Cape, Gauteng } \\
\text { and Limpopo, not listed elsewhere. }\end{array}$ & - \\
\hline
\end{tabular}


TABLE 1-A2 (Continues...): Analysis of the current list and issues arising from the list.

\begin{tabular}{|c|c|c|c|c|}
\hline Issue & Description & \# taxa & Examples & Recommendation \\
\hline $\begin{array}{l}\text { Listing of native } \\
\text { taxa }\end{array}$ & $\begin{array}{l}\text { Issues around listing of native but } \\
\text { extralimital species and hybrids. }\end{array}$ & List 6 Species 6 & $\begin{array}{l}\text { Xenopus laevis } \mathrm{x} \text { Xenopus gilli hybrids } \\
\text { are listed as Category } 1 \mathrm{~b} \text {. }\end{array}$ & - \\
\hline $\begin{array}{l}\text { Geographical } \\
\text { listing }\end{array}$ & $\begin{array}{l}\text { Listings of taxa in certain provinces or } \\
\text { areas, but not others, or different } \\
\text { categories in different regions. }\end{array}$ & List 5 Species 8 & $\begin{array}{l}\text { Boa constrictor is only listed as } \\
\text { Category } 2 \text { in KwaZulu-Natal, } \\
\text { Mpumalanga, Eastern Cape, Gauteng } \\
\text { and Limpopo, but not listed elsewhere. }\end{array}$ & $\begin{array}{l}\text { Geographic listings should be assessed for, and plans } \\
\text { to combat translocation be put in place. }\end{array}$ \\
\hline Listing on islands & Some taxa are only listed on islands. & List 1 Species 26 & $\begin{array}{l}\text { Agrostis castellana is listed as } 1 \mathrm{a} \text { on } \\
\text { Prince Edward Island, } 1 \mathrm{~b} \text { on Marion } \\
\text { Island, not listed on the mainland. }\end{array}$ & $\begin{array}{l}\text { Taxa listed on islands should be listed with a strategy } \\
\text { of prohibiting further introduction or eradication } \\
\text { plans. }\end{array}$ \\
\hline $\begin{array}{l}\text { Specification of } \\
\text { permit } \\
\text { conditions }\end{array}$ & $\begin{array}{l}\text { For a few species, conditions for permit } \\
\text { applications are given. }\end{array}$ & $\begin{array}{l}\text { List } 3 \text { Species } \\
\text { 14, Species } 18\end{array}$ & $\begin{array}{l}\text { Hydrochaeris is listed as Category 2, but } \\
\text { prohibited for the following activity: } \\
\text { 'Growing, breeding or in any other way } \\
\text { propagating any specimen of a listed } \\
\text { invasive species, or causing it to multiply'. } \\
\text { Erythrocebus patas is only Category } 2 \text { if } \\
\text { bred for export, otherwise 1a or 1b, } \\
\text { depending on region. }\end{array}$ & $\begin{array}{l}\text { Permit conditions should be explicitly provided for all } \\
\text { Category } 2 \text { species, and clarified conditions under } \\
\text { which a permit can be disapproved }\end{array}$ \\
\hline $\begin{array}{l}\text { Other specified } \\
\text { listing conditions }\end{array}$ & & List 7 Species 3 & $\begin{array}{l}\text { Many fish species are listed under very } \\
\text { specific conditions. }\end{array}$ & $\begin{array}{l}\text { The more exemptions and conditions, the harder it } \\
\text { gets to regulate these taxa. }\end{array}$ \\
\hline Authority & $\begin{array}{l}\text { For most taxa, the authority is given, } \\
\text { but not always. }\end{array}$ & List 11 species 1 & $\begin{array}{l}\text { For Kirramyces destructans (listed as } \\
\text { 1b), no authority is provided. }\end{array}$ & Authorities should be provided for all taxa. \\
\hline
\end{tabular}

\section{Appendix 3}

TABLE 1-A3: Systematic differences between versions of published lists to the first promulgated version, 2009-2014.

\begin{tabular}{|c|c|c|c|c|c|c|}
\hline Change & Description & Example & 2009 & 2013 & 2014a & 2014b \\
\hline Order of listing & $\begin{array}{l}\text { The order in which the lists were } \\
\text { arrangement changed at any point in time. }\end{array}$ & $\begin{array}{l}\text { Prohibited species were put first in } 2009 \text { and } \\
\text { last in 2014b. }\end{array}$ & $\mathrm{n} / \mathrm{a}$ & $\mathrm{n} / \mathrm{a}$ & $\mathrm{n} / \mathrm{a}$ & $\mathrm{n} / \mathrm{a}$ \\
\hline $\begin{array}{l}\text { Table of content of lists } \\
\text { provided }\end{array}$ & $\begin{array}{l}\text { A list of titles of the parts of document } \\
\text { organised in the order in which the parts } \\
\text { appear. }\end{array}$ & Notice 3, National List of Invasive species. & $\mathrm{N}$ & $\mathrm{N}$ & Y & Y \\
\hline $\begin{array}{l}\text { Sub-listings with details of } \\
\text { total number of listed } \\
\text { species }\end{array}$ & $\begin{array}{l}\text { The sub-categorisation of the list into } \\
\text { individual subsets. }\end{array}$ & $\begin{array}{l}\text { Notice 3, List 1: National List of Invasive } \\
\text { Terrestrial and Fresh-water Plant Species and } \\
\text { List 3: National List of Invasive Mammal Species. }\end{array}$ & $\mathrm{N}$ & $\mathrm{N}$ & Y & Y \\
\hline List start with plants & $\begin{array}{l}\text { A living organism of the kind exemplified by } \\
\text { trees, shrubs, herbs, grasses, ferns and } \\
\text { mosses. }\end{array}$ & $\begin{array}{l}\text { Notice } 3 \text {, List } 1 \text { species } 2: \\
\text { Acacia baileyana F. Muell. }\end{array}$ & $\mathrm{N}$ & $\mathrm{N}$ & Y & Y \\
\hline $\begin{array}{l}\text { List start with terrestrial } \\
\text { invertebrates }\end{array}$ & $\begin{array}{l}\text { Invertebrates are a group of animals that } \\
\text { have no backbone like spider. }\end{array}$ & $\begin{array}{l}\text { List 3, Species } 13 \\
\text { Aedes albopictus. }\end{array}$ & $\mathrm{Y}$ & $\mathrm{Y}$ & $\mathrm{N}$ & $\mathrm{N}$ \\
\hline $\begin{array}{l}\text { Individual taxa entries } \\
\text { numbered }\end{array}$ & $\begin{array}{l}\text { The numbering of listed species in numerical } \\
\text { order. }\end{array}$ & $\begin{array}{l}\text { Notice } 3 \text {, List } 11 \text {, Species } 6 \text { : } \\
\text { Teratosphaeria cryptica. }\end{array}$ & Y & $\mathrm{N}$ & Y & Y \\
\hline Microbial species listed & $\begin{array}{l}\text { Microbes are microorganisms, especially a } \\
\text { bacterium, fungi and virus. }\end{array}$ & Phytophthora kernoviae. & $\mathrm{N}$ & $\mathrm{N}$ & Y & Y \\
\hline $\begin{array}{l}\text { Description of a fish } \\
\text { sanctuary area }\end{array}$ & $\begin{array}{l}\text { Fish sanctuary areas means areas fish } \\
\text { sanctuary areas in the national freshwater } \\
\text { ecosystem priority area amps. }\end{array}$ & Described in 2014a. & $\mathrm{N}$ & $\mathrm{N}$ & Y & $\mathrm{N}$ \\
\hline Listed taxa referred to as list & $\begin{array}{l}\text { Categorisation of listed groups by NEM:BA } \\
\text { regulation. }\end{array}$ & Notice 3, List 2. & $\mathrm{~N}$ & $\mathrm{~N}$ & $\mathrm{Y}$ & Y \\
\hline $\begin{array}{l}\text { Freshwater and anadromous } \\
\text { fish }\end{array}$ & $\begin{array}{l}\text { Means the fish sanctuary areas demarcated } \\
\text { in the National Freshwater Ecosystem priority } \\
\text { area maps for critically endangered species } \\
\text { published by the Water Research Commission } \\
\text { in report TT500/11 as amended from time } \\
\text { to time. }\end{array}$ & Pterygoplichthys disjunctivus. & $\mathrm{N}$ & $\mathrm{Y}$ & $\mathrm{N}$ & $\mathrm{N}$ \\
\hline Only two categories provided & Categories as provided by NEM:BA regulations. & Category $1 \mathrm{a} \& \mathrm{1b}$. & $\mathrm{N}$ & Y & $\mathrm{N}$ & $\mathrm{N}$ \\
\hline Four categories provided & Categories as provided by NEM:BA regulations. & Category 1a, 1b, 2, 3. & Y & $\mathrm{N}$ & Y & Y \\
\hline $\begin{array}{l}\text { Scope of exemption was } \\
\text { sometimes provided }\end{array}$ & $\begin{array}{l}\text { The degree to which the species are not } \\
\text { regulated by NEM:BA regulations. }\end{array}$ & $\begin{array}{l}\text { Acacia mearnsii De Wild Exempted for an } \\
\text { existing plantation. }\end{array}$ & Y & $\mathrm{N}$ & $\mathrm{Y}$ & Y \\
\hline $\begin{array}{l}\text { Category and area for } \\
\text { categorisation of regulation }\end{array}$ & $\begin{array}{l}\text { A category of regulation as described by } \\
\text { NEM:BA regulations. }\end{array}$ & $\begin{array}{l}\text { a. } 2 \text { b. } 1 \mathrm{~b} \text { within } 100 \mathrm{~m} \text { of riparian areas or } \\
\text { untransformed land. }\end{array}$ & $\mathrm{N}$ & $\mathrm{N}$ & Y & Y \\
\hline $\begin{array}{l}\text { Reptiles and amphibians } \\
\text { combined }\end{array}$ & $\begin{array}{l}\text { A cold-blooded vertebrate animal of the class } \\
\text { Amphibia and a cold-blooded vertebrate } \\
\text { animal of the class Reptilia. }\end{array}$ & $\begin{array}{l}\text { Hyperolius marmoratus in same list as Bitis } \\
\text { nasicornis. }\end{array}$ & Y & $\mathrm{N}$ & $\mathrm{N}$ & $\mathrm{N}$ \\
\hline Indigenous species listed & $\begin{array}{l}\text { Is a plant, fungus or animal species that is } \\
\text { native to a specific location (an introduced } \\
\text { species). }\end{array}$ & Cephalophus natalensis. & $\mathrm{Y}$ & $\mathrm{N}$ & $\mathrm{N}$ & $\mathrm{N}$ \\
\hline $\begin{array}{l}\text { Consistency in use of } \\
\text { authorities in listing species }\end{array}$ & $\begin{array}{l}\text { The taxonomic authority is the name of the } \\
\text { person or people who published the original } \\
\text { description for a particular scientific name, } \\
\text { followed by the year of publication. }\end{array}$ & $\begin{array}{l}\text { Oryx dammah (Cretzschmar 1827) } \\
\text { Tragelaphus spekii P.L. Sclater, } 1863 .\end{array}$ & Y & $\mathrm{Y}$ & $\mathrm{Y}$ & Y \\
\hline Exemption of sterile cultivars & $\begin{array}{l}\text { A plant variety that has been produced in } \\
\text { cultivation by selective breeding. }\end{array}$ & $\begin{array}{l}\text { Ageratum houstonianum Mill. In 2014a Sterile } \\
\text { cultivars or hybrids exempted. }\end{array}$ & $\mathrm{N}$ & $\mathrm{N}$ & Y & $Y$ \\
\hline
\end{tabular}

NEM:BA, National Environmental Management: Biodiversity Act. 


\section{Appendix 4: Estimations of cost of development of list of regulated alien and invasive species in South Africa}

If we look at the meeting attendance as 'person days' - that is, 288 person days of meeting.

Assume meeting participants needed a day of preparation for each meeting (this is a conservative estimate) means +288 days.

About half of the participants at each meeting had to travel so add on 144 days of travel time.

Plus about 31 days of comments where folk did not attend meetings $=751$ person days. If there are 120 working days per annum, this equates to 6.25 years of senior staff time. Most participants would have been Level 10 or above (including directors and Deputy Director General [DDGs]).

Then, add a year of the following people's time: John Donaldson, Ernst Swart and Ingrid Nanni (John and Ernst were senior, Ingrid was less senior, but was assisted by three support staff so salary would even out at a senior level).
This means that in terms of person days, the lists took 9.25 years!! Remember I have not added DEA staff time when they tabulated and responded to comments, nor the time spent BEFORE SANBI took the lead, or the time spent AFTER SANBI handed over the lists to DEA (they must have spent time on them because the final lists were not the same as the ones SANBI handed over).

If we use Salary Level 10 as an average (I think this is conservative considering the seniority of the participants).

Current Level 10 Notch 1 salary is R389 145 plus 37\% (benefits) R143 983 = R533 128.

Multiply by 9.25 years is R4.9m for salaries alone (R4 931434 ). It would not be unrealistic to round this up to $\mathrm{R} 5 \mathrm{~m}$.

On top of this is the cost to company of employing those staff (computers, desk space, telephone or printing, etc.) and the cost of the venues (we did not ever pay for meeting venues but essentially, there was a cost which SANBI carried), and the cost of facilitation ca. R200 000 .

So, a conservative estimate of the cost of drawing up the lists during the year that SANBI was facilitating the process (at current rates) is between $\mathrm{R} 5.5 \mathrm{~m}$ and $\mathrm{R} 6 \mathrm{~m}$. 